\title{
Article
}

\section{Introduction to Special Issue on Visual Culture}

Mihalopoulos, Bill

Available at http://clok.uclan.ac.uk/30730/

Mihalopoulos, Bill ORCID: 0000-0001-6112-6094 (2020) Introduction to

Special Issue on Visual Culture. Japan Forum, 32 (1). pp. 3-5. ISSN 0955-5803

It is advisable to refer to the publisher's version if you intend to cite from the work.

http://dx.doi.org/10.1080/09555803.2019.1694563

For more information about UCLan's research in this area go to

http://www.uclan.ac.uk/researchgroups/ and search for < name of research Group>.

For information about Research generally at UCLan please go to http://www.uclan.ac.uk/research/

All outputs in CLoK are protected by Intellectual Property Rights law, including Copyright law. Copyright, IPR and Moral Rights for the works on this site are retained by the individual authors and/or other copyright owners. Terms and conditions for use of this material are defined in the policies page.

\section{CLoK}

Central Lancashire online Knowledge www.clok.uclan.ac.uk

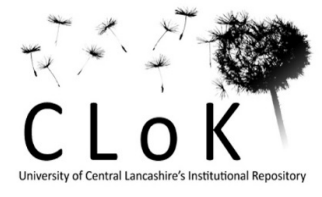


Introduction to Special Issue on Visual Culture

Bill Mihalopoulos

The articles in this special issue explore visual culture as both cultural artefact and historical document. In their own way, each article sheds light on the image-creating medium rather than the image-interpreting medium. Despite methodological differences, the common theme that binds together this special issue is a shared awareness that visual objects draw events and elements from the materiality that constitutes the world, and in the process, reconfigure both knowledge and cognitive experience. The authors recognise that visual culture is a labour of fiction; a reframing of the real via changing modes of sensory perceptions that build new relationships between reality and appearance (Rancière 2018: 149).

This compilation of articles wrestles with a conflict that runs through Japanese thinking since the mid-Tokugawa period: do we take knowledge as experience or do we treat experience as the object of knowledge. As a collective, these articles are an antidote to recent efforts in theology that sutured history to experience. One such moment was the historiography that dominated Japanese academia until the end of the Pacific War. Japan's imperial historians stitched empirical positivism to myth, imperial charisma to manifest destiny, articulating a historical trajectory where Japan would liberate Asia from 300 years of Western domination. Another key moment was the post-war rehabilitation of Japan into a bifurcated world defined by the epochal struggle between East and West. In the West at least, Japan's return to the global community was framed by grafting the "value-free" empirical fields of the social sciences to the utopia of capitalist progress, which showcased Japan as a model of political and economic non-revolutionary change (Harootunian 2019: 9). 
Opening this special issue, Elisabeth Scherer and Timo Thelen investigate NHK's morning drama series (asadora), which has a special presence in the rituals of everyday life for millions of viewers. Scherer and Thelen argue that asadora acts as a meditator for traditional 'Japanese' values and functions as a medium of collective memory. Using the example of the 2015 asadora Mare set in the port city of Wajima in Ishikawa Prefecture, the authors explore the linkage between TV production and regional tourism aimed at revitalising ailing regional economies. Via their study of contents tourism in the making of the Mare series, Scherer and Thelen trace the negations between real and imagined landscapes and how the past is reframed to shape the leisure industry as well as regional identity.

In his article on the processional prints of the Kanda festival, Ezra Toback takes popular visual art as a form of inflected historical evidence that reveals linkages between sacred and civic events, neighbourhood identities and the commercial publishing industry. He sheds light on the dialogical relationship - the interplay of form and content - between popular art and the neighbourhood identities of the parishioner consumers. Toback argues that the efficacy of art lies in having living bodies directly embody the common. Neighbourhood identities crystalise around the inflections of the popular art's morphology, iconography and setting via the mass dissemination of visual images, reinforcing the foundations for community affiliation.

Philip Charrier's article focuses on Nakahira Takuma and his search for a new aesthetic that would rescue the photographic image from the fads of commerce. Charrier traces Nakahira's aesthetic quest to strip photography to its most basic mode of action by rejecting the notion that artists were the creators of meaning and idealism toward a better world. Through an aesthetic of directness and optical honesty, Nakahira reframed the photographer as an 
extension of the camera's objective mechanical eye, able to resist deception and see through falsity, thus altering the relationship between the self and the world.

The final article by Bill Mihalopoulos focuses on three documentaries made by Imamura Shōhei in the early 1970s that directly challenge narratives that valorised the Japanese state as an agent of progress. Imamura uses the medium of cinema to render visible the way the body of the unreturned solider, via the associations made with its environment and other bodies, was a site of multiple temporalities incompatible with the chronological linear narrative that constituted the history of the Japanese nation state. The documentaries interrogate how Japan's relations with other Asian nations are deformed by the ruse of memory, focusing specifically on Japanese war responsibility and the unfinished history of the Pacific War: a war that is not a problem of yesterday but of today.

This collection of essays reminds us that knowledge and experience are two sides of the same coin. The articles, as a collective, draw attention to the fact that knowing is constituted by the interface of multiple and different modes of seeing and speaking - a moving field of cognitive experiences where the subject and object are constantly modified in relationship to each other as fragments of the past are marshalled to reframe the present.

\section{Works Cited}

Harootunian, Harry (2019), Uneven Moments: Reflections on Japan's Modern History, New York: Columbia University Press.

Rancière, Jacques (2018), Dissensus: On Politics and Aesthetics, London: Bloomsbury Academic. 